Please do not remove this page

RMIT

UNIVERSITY

\title{
Weaving words: Law and performance in early Nordic tradition
}

Mees, Bernard

https://researchrepository.rmit.edu.au/esploro/outputs/9921861940401341/filesAndLinks?institution=61RMIT_INST\&index=null

Mees, B. (2013). Weaving words: Law and performance in early Nordic tradition. Amsterdamer Beiträge Zur Älteren Germanistik, 70, 131-150.

https://researchrepository.rmit.edu.au/discovery/fulldisplay/alma9921861940401341/61RMIT_INST:Resea rchRepository

Document Version: Accepted Manuscript

Repository homepage: https://researchrepository.rmit.edu.au

(C) Rodopi 2013

Downloaded On 2023/04/26 09:31:33 +1000

Please do not remove this page 
Thank you for downloading this document from the RMIT Research Repository.

The RMIT Research Repository is an open access database showcasing the research outputs of RMIT University researchers.

RMIT Research Repository: http://researchbank.rmit.edu.au/

\section{Citation:}

Mees, B 2013, 'Weaving words: Law and performance in early Nordic tradition', Amsterdamer Beiträge zur älteren Germanistik, vol. 70, pp. 131-150.

See this record in the RMIT Research Repository at:

http://researchbank.rmit.edu.au/view/rmit:20812

Version: Accepted Manuscript

Copyright Statement: (c) Rodopi 2013

Link to Published Version:

http://www.ingentaconnect.com/content/rodopi/abag

\section{PLEASE DO NOT REMOVE THIS PAGE}




\title{
Weaving Words
}

\author{
Law and performance in early Nordic tradition
}

Bernard Mees (Royal Melbourne Institute of Technology)

\begin{abstract}
The reference to málrúnar or 'speech runes' in Sigrdrífumál suggests a performative aspect to the practice of early Germanic law that transcends the swearing of oaths and the reciting of law codes attested to by literary sources. Indeed early runic texts often feature alliteration, much as do the old Scandinavian legal tracts. This parallelism suggests that early Northern legal language was not stylised merely for mnemonic purposes, but instead reflects an oral-performative praxis similar to that which appears to be reflected in early Irish sources. But the relationship between performance and memorisation has not always been demarcated clearly in recent scholarship. Oralperformative theory is often called upon today without reference to explanations of social action. The privileging of generative performance over pre-literate memory culture seems to represent only an awkward victory of the medievalistic "anthropological turn" over other key expressions of socio-cultural theory.
\end{abstract}

\section{Introduction}

Ba dorcha didiu in labra ro labrasatar ind filid isin fuigiull-sin 7 nírba réill donaib flathaib in brethemnus ro-n-ucsat.

'Dark was the speech which the filid spoke in that case, and the judgement which they gave was not clear to the princes.'

This alliterating description from the Pseudo-historical Prologue to the Old Irish Senchas Már (Carey 1994, §10) provided Robin Chapman Stacey with the title of her prize-winning 2007 book Dark Speech on the performance of law in medieval Ireland. The 'dark speech' of the filid referred to in the Prologue seems to represent a reflection of the appearance of many highly stylised (and often well-nigh impenetrable) passages in the surviving Old Irish law tracts. Stacey duly interprets this tradition as reflecting the usual proclivity for lawyers in all cultures and climes to develop their own stylised, often inscrutable (and excluding) form of language indeed one of a kind that might reasonably be assumed to have a counterpart in Old Norse experience too.

\section{Old Norse málrúnar}

The best-known instances of stylised speech used in medieval Norse legal discourse are the paired formulations which are so well attested in early Northern tradition, most such evidence for which is recorded in the form of Old Scandinavian law codes. ${ }^{1}$ The use of meristic pairs of this sort is well known from other legal traditions, however, so such expressions do not seem particularly remarkable from a cross-linguistic or cross-

\footnotetext{
${ }^{1}$ See Vendell (1897), Dilcher (1961), Ehrhardt (1977), Fix (1982), Brink (2005, 74-77), Schulte (2011).
} 
cultural perspective (cf. Tiersma 2000). But there are also some suggestions that stylised language was used in broader Norse legal practice in a manner comparable to the 'dark speech' of Old Irish experience. For example, Sigrdrífa counsels Sigurðr concerning how to use málrúnar in the rune-lore section of Sigrdrífumál (12) in a manner that seems to represent a legalistic sensibility: ${ }^{2}$

Málrúnar scaltu kunna, if pú vilt, at magni pér

heiptom gialdi harm;

per um vindr, per um vefr,

per um setr allar saman

á pví pingi, er pióðir scolo

í fulla dóma fara

'Speech-runes you shall know, if you want no-one

to repay you harm with hatred;

wind them about, weave them about,

and place them all together

at the assembly, where people shall

for full judgment go.'

The notion of 'weaving' or 'winding' words is a well-known trope of (Indo)European experience (West 2007, 36-38). But what málrúnar (literally 'speechrunes') would have to do with arguing a legal (or perhaps political) case at an assembly (bing) is not immediately clear. Relying on an etymological development of *mapl-/mahl- 'assembly' > mál 'a speech (given at an assembly)', Markey (1998, 195-96) speculates that málrúnar may have (originally) signified written pleas (etc.) made at legal hearings (i.e. at assemblies). The evidence he produces for collocations of *mapl-/mahl- and *rūnō, however, suggests that the málrúnar of Sigrdrífumál represent a conflation of what at first appears to be a (semi-)grammatical term (cf. ON rúnamál 'the runic alphabet', málstafr 'letter of the alphabet') with a much older tradition of *mapl-/mahla-rūnōz as representing legal counsel. Witness especially Markey's example of a collocation taken from the Old Saxon Heliand (1311-12):

thie rincos, thie hîr rehto adômiad, ne uuilliad an rûnun besuuîcan man, that sie at mahle sittiad

'these men, who here judge justly, do not intend to deceive men in counsel when they sit at the assembly.'

Yet málrúnar have long usually been understood in terms of a definition of dróttkvaett given by Snorri (Snorra Edda 121):

Detta er dróttkvaðr háttr.

Með peima hatti er flest ort pat er vandat er.

Pessi er upphaf allra hátta, sem málrúnar eru fyrir oðrum rúnum.

\footnotetext{
${ }^{2}$ Cf. also $G \partial r$ I, 23.
} 
'This is dróttkvaett form.

This is the form most often used for elaborate poetry.

This is the foundation of all verse-forms

just as málrúnar are the principal sort of runes.'

Thus málrúnar is translated by Moltke $(1985,460)$ as 'plain speech-runes', the compound seemingly understood by Snorri as signifying a form of runes opposed to cryptic runes (and the like). Indeed as Bauer (2010) has shown, the description málrúnar is used in Icelandic sources from the seventeenth century and later in opposition to galdrarúnir (magical glyphs) and other similar late expressions. Yet Snorri is defining dróttkvatt in this passage as a form of poetry; interpreting málrúnar in terms of (comparably) elevated language would necessarily mean a different translation of málrúnar. What if, for example, Snorri meant 'the best use of runes, a poetic use of runes' by fyrir oðrum rúnum?

Indeed 'the best use of runes' or 'the most prestigious use of runes' is precisely what one of the Lund bone inscriptions seems to indicate by málrúnar: Bōndi risti mālrūnu: ārar ara eru fjadhrar, 'Bondi carved mälrūnar: the oars of the eagle are (its) feathers' (Moltke 1985, 460). And despite Moltke, the Lund find clearly suggests that the most prestigious use of runes was to use runes to write poetry - or at least to write in an elevated form. Most of the other uses of runes suggested by the rune-lore of Sigrdrífumál can be paralleled in other literary accounts of runic magic (MacLeod and Mees 2006, 238-44), but the notion that málrúnar were merely runic words (or a form of advice) that were composed (or articulated) in a stylised or heightened manner appears to be the best understanding for the three attestations of málrúnar in medieval Scandinavian use. Indeed the otherwise unparalleled hugrúnar or 'mindrunes' which are described immediately afterwards in Sigrdrifumál 13 appear to represent a similar appeal to poetic perspicacity:

Hugrúnar scaltu kunna, ef pú vilt hverjum vera

geðsvinnari guma;

par of réð, par of reist,

par of hugði Hroptr,

af peim legi, er lekit hafði

ór hausi Heiðdraupnis

ok ór horni Hoddrofnis.

'Mind-runes you shall know, if you want to be a wiser man than every other.

Interpreted them, carved them,

devised them did Hroptr,

from the fluid which had leaked

from Heiddraupnir's head

and from Hoddrofnir's horn.'

It seems quite clear here that -rúnar has been influenced by the non-orthographic use of the form parallelled in Celtic (cf. OIr. rún 'hidden, occult, mystery, secret, knowledge', MW rhin 'virtue, secret, mystery, charm') - i.e. as a reference to (secret) 
verbal counsel (cf. OE rūnwita 'adviser, counsellor', Goth. rūna 'mystery', rūna niman 'take counsel'). Consequently málrúnar would similarly seem to represent a comparable reference to a special form of rhetoric or wisdom, mál originally indicating a particular type of * rūnō or 'counsel'.

Indeed as Markey (1998) argues, the descendants of *mapl-/mahl- have a decidedly legalistic use throughout Germanic. And the opposition of eiða vinna ... málom slita (oaths make ... agreements break) of Grípisspá (31-32) suggests that the notion málrúnar may also have had an especially legalistic colouring. After all, there are runic attestations of what would appear to be stylised legal language - and not just in terms of epigraphically attested legal codification. The inscription on a wroughtiron ring from Forsa, Hälsingland, shows that alliteration was already a part of legal codification by the tenth century. ${ }^{3}$ And the curses which appear on runic memorials the earliest of which go back to the transitional runic period - represent pseudo-legal texts that often feature alliteration (Jacobsen 1935, MacLeod and Mees 2006, 112-14 and 223-25). Whether expressions like the warnings on the Blekinge stones represent actual verse or not has been a matter of some disagreement, Schulte (2010, 56-58), for example, only willing to accept that the Stentoften and Björketorp texts feature alliterating prose. Yet the earliest Northern texts which seem to have had a legal function date from the older runic period and are stylised much as if they were considered to be poetry.

\section{Early runic evidence}

The best-known example of such a text is that on the Tune stone (NIaR no. 1; Krause and Jankuhn 1966, no. 72) which, as has long been recognised, seems to make reference to an inheritance. Usually dated to about the end the fourth or beginning of the fifth century (albeit not on particularly reliable grounds), the early Norwegian memorial inscription rediscovered in 1627 also preserves several linguistic features typical of inscriptions from the older runic period. Although it has been read differently by Grønvik (1981; 1994, 48-49; 1998 and cf. Spurkland 2005, 35-42), the traditional interpretation of the text as two complete (boustrophedon) sentences seems best justified by what is actually attested orthographically (Krause and Jankuhn 1966, no. 72):

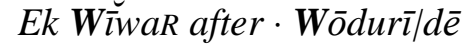
wita(n)deh ${ }^{a}$ laiban : wor ${ }^{a}$ htō : r [ $\left.\bar{u} n \bar{o} R\right]$ runes.

[---]R Wōdurīdè : staina .

prijōe dohtriR dālidun

arbija (a)rjōstēe arbijanō heirs.'
'I, Wiwar, in memory of WoduridaR, the loaf-warden, wrought (these)

... for WoduridaR, a stone, three daughters prepared a funeral feast, the noblest (?) of

The Tune inscription is much more complex and indeed longer than older runic

\footnotetext{
${ }^{3}$ See Liestøl (1979), Ruthström (1990), Brink (1996; 2008, 28-29), Källström (2010), Schulte (2011, 18-20).
} 
memorials usually are. Nonetheless what is generally taken to be the first (or side A) section of the early Norwegian text represents a fairly typical runic memorial formula ('X made/raised in memory of $\mathrm{Y}$ ') featuring alliteration which builds upon that provided by the names of the deceased and the first-person agent or subject-author of the inscription. It is not clear whether the expression usually reconstructed as $r$ [unnōR] was ever present on the stone and a form ending in what until the 1980s had generally been read as an - $\mathbf{R}$ is similarly missing where the text resumes on side B of the monument. Yet the extension of the euphonic decoration both to what has usually been taken to be the memorialised's functional title wita(n)deh laiban as well as the fabricant verb is hardly likely to have been accidental - the text has evidently been stylised considerably more than was strictly necessary. Indeed the verb-late (rather than verb-second) opening word order also seems rather unexpected unless the text is poetic (Eythórsson 2001, 25-26). Nonetheless Dishington (2009) has recently argued that a more legalistic witad-aha-laiban 'whose estate is planned and certain' is to be understood for witadâhalaiban and Moltke $(1985,79)$ claimed that the use of ON $y r k i$ in the sense 'make a verse', 'compose poetry' could explain the use of *wurkjan 'make' here (cf. Grønvik 1981, 148-61), an association which is widely paralleled in other Indo-European languages (West 2007, 35-36). After all, alliteration can similarly be found in the inscription on side B of the stone, and moreover this part of the text is even more radically mannered syntactically - i.e. it takes a form that can scarcely be put down to a simple topicalisation or another pragmatic feature typical of unmannered oral language or prose. The syntactic contortion of the second orthographic sequence on the Tune memorial is so remarkable it seems hard to explain other than as being due to a deliberate practice comparable to versification. Hence Lehmann's $(1956,78)$ rather controversial attempt to read the Tune text as a primitive form of ljóðaháttr. ${ }^{4}$

Two main interpretations have emerged for side B of the Tune memorial, however, and of these, the traditional reading proposed by Bugge (NIaR no. 1), largely supported by Marstrander (1930) and Krause (in Krause and Jankuhn 1966, no. 72), is remarkable in two ways. Bugge read the final line as arbija sijoster arbijano, with the middle term a contraction of a mooted *sibijōstēR 'most closely related' whereas Marstrander (1930, 320-21) preferred to read a scriptio continua a(n)sijōstēe 'godliest' here. Nonetheless in 1934 Krause instead suggested an Aryanising interpretation of the unclear middle sequence which has since been supported (at least etymologically) by the discovery of a Gaulish term ariios (presumably meaning 'noble' or 'chief') on a dedication that was first published in the 1950s; see Lejeune (1971, 46-47) and also Antonsen (2002, 128-29) for an epigraphic defence of Krause's (reversed) r-reading arjoster 'noblest, most Aryan'. Grønvik (1976, 159$63 ; 1981,181-84)$, however, preferred to compare the form with ON anna 'be able, take care of, support, be busy', suggesting a reading $a(n)$ sijostēe 'kindest' for the controversial sequence - but this does not represent an obvious linguistic improvement on previous interpretations either (cf. Spurkland 2005, 39). Perhaps more notably, though, the traditional interpretation of side $\mathrm{B}$ of the memorial stone (as it is represented in Krause's corpus) allows for one verb, but two objects, suggesting that some sort of apo koinou or pivot construction (cf. Meritt 1938; Norén 2007) was

\footnotetext{
${ }^{4}$ Cf. Naumann (1998, 697; 2010, 151-52), Marold (2001, 538-39; 2011, 75-78), Schulte (2009, 12-13; 2010, 54-55).
} 
intended by the inscriber, i.e.: ${ }^{5}$

... Wōdurīdē staina prijōR dohtriR dālidun

dālidun arbija arjōstēe arbijanō.

'...for WoduridaR, a stone, three daughters prepared

(they) prepared a funeral feast, the noblest

(?) of

heirs.'

The unclear opening form on side B at Tune was interpreted by Bugge as [afte]R (with an -R rather than the expected -r), but later by Marstrander and Krause as a benefactive pronoun $[m \bar{e}] R$ 'for me' and by Lehmann (on alliterative grounds) as $[p \bar{e}] R$ 'for thee'. Yet Grønvik (1981, 168-75; 1994, 48-49) has more recently instead sought to read a verb before the dative form Wōdurīde (appearing, atypically for early runic texts, in sentence-initial position) which would lessen some of the syntactic complexity of the side B text. Indeed Knirk (2006) similarly simplifies the inscription by assuming that ... Wōdurìde staina represents the end of a discrete sentence (albeit without speculating on what the missing verb might have been). Grønvik's pronominally elided (or pro-drop) 1981 reading [fal]h (for expected [fal $\left.\left.{ }^{a}\right] h\right)^{6}$ Wōdurìdē staina. Prijōo dohtriR dālidun arbija, āsijōstēe arbijanō, ' ‘... entrusted the stone to WoduridaR. Three daughters arranged the funeral feast, the kindest (?) of funeral-feast preparers' or even his more epigraphically conservative interpretation of the damaged term as $[e-\bar{e}] R$... 'honoured ...' from $1994^{7}$ (albeit recanted in Grønvik 1998, 36-38) still assumes some unexpected syntactic behaviour, however: under either syntactic interpretation, the alliterating superlative description of the Tune daughters (which grammatically is clearly a noun phrase that describes prijō $R$ dohtriR) has evidently been dislocated rightwards in a typical afterthought-like manner (cf. Altmann 1981, 70-72), the subject and its adjectival modifier prijōR reversed from the usual early runic (head, modifier) ordering seemingly only (rather than as a sign of emphasis) in order to enable dohtriR to stand next to dälidun, the (alliterating) verb (contrast staba prija, acc. 'three staves' at Gummarp; Krause and Jankuhn 1966, no. 95). The (presumably) benefactive (if not recipient) Wōdurìdē on side B follows the unexpected order of dative, accusative presumed (also) for the sentence on side A, albeit coming in post-verbal position (i.e. assuming that Grønvik and others are right to reconstruct a missing verb here). Hence Grønvik's interpretation evidently still requires the acceptance of considerable (and unexpected) syntactic (not to mention semantic) complexity, the traditional reading of side B of the Tune inscription in contrast requiring less epigraphic presumption than does Grønvik's scheme.

Nonetheless Grønvik's pronominally elided verb-first reading (whether [fal]h or

\footnotetext{
${ }^{5}$ Cf. Krause's $(1971,170)$ apo koinou translation "dem Wodrid den Stein || drei Töchter bereiten, || das Erbmahl (aber) die vornehmsten der Erben".

${ }^{6}$ As Antonsen $(2002,128)$ points out, the epenthetic Tune spellings -hâlaiban and worahto suggest that a similar development should have transpired in Grønvik's putative *falh, an observation which undermines Grønvik's 1981 reconstruction as given a reading -h, only three stems (not four) remain of the missing runes at the beginning of side $\mathrm{B}$ of the memorial inscription today.

${ }^{7}$ Perhaps more regularly to be understood as [ek ai] $R$ 'I have dedicated' with the typical early runic ligaturing of $\mathbf{e}+\mathbf{k}$, rather less odd vocalism and an inherited usage of PG *aiz- suggested by the Oscan cognate aisusis 'sacrifice'.
} 
$[e-\bar{e}] R$ ) presumably still suggests a legal action (or assertion of a right) connected with inheritance is to be seen on side B of the Tune stone, an interpretation only strengthened by Dishington's new analysis (if it is to be accepted) of side A's witadahalaiban. A two-sentence interpretation of side B of the memorial text also explains the use of arbija as the single direct object of the 3rd pl. verb (even if reading 'funeral feast' here, rather than the etymologically inherited meaning 'inheritance' represented by Goth. arbi, OE ierfe and OHG erbi 'id.', was criticised by Antonsen 2002, 129-30). Indeed the dual objects of Krause's traditional reading were not allowed by Antonsen (either) who preferred to read a compounded form arbijarjōstēz 'inheritance foremost' for the difficult sequence in his single-sentence interpretation of side B of the stone (Antonsen 2002, 130).

Thus most of the dispute over the correct reading of the Tune memorial would appear to stem not (just) from the lacunae, but (also) from the linguistic stylisation that is clearly to be recognised in the find, no matter which of the interpretations is taken to be correct. Yet whatever the precise type of stylisation attested in the inscription, at the very least the alliterating memorial text seems to assert the right of the three daughters of WoduridaR to hold the land about the stone, just as medieval Irish law maintained that in property disputes 'the ogam (inscription) in the standing stone ... is like a witness' (Int oghom isin gollán ... amal fiadain hé; CIH 1566.6-7). The Tune daughters may have had a less agentive commemorative role because of typically restrictive feminine social gender construction, the commissioning of the inscription (as a form of *mapla-/mahla-rünōz) presumably serving much more than merely a simple memorial function.

Another example of an alliterating older runic text which seems to feature a legal aspect is more difficult to read. The latter parts of the inscription from Myklebostad, Nordland, which seems to date to the fifth or first half of the sixth century, are quite weathered and hard to make much sense of today. Yet the part of the early Norwegian runic text that can clearly be understood seems to feature both irregular syntax and alliteration of the nominative subject and the verb, as is only too common in early Nordic epigraphy (cf. Nielsen 1969; 1984:10; Naumann 2010, 148). Moreover the final expression (which is usually taken to represent a second man's name) even has the look of a typical 'snake' kenning to it - i.e. what usually turn out to be references to gold when they appear in Old Norse literature (cf. ormbekkr, ormlátr, ormsetr etc.). Krause (in Krause and Jankuhn 1966, no. 77) read the early Nordic text (which appears on a stone that has been cut in two, the separate sections of which were unearthed in 1852 and 1888 respectively) in much the same manner as has Knirk (2002):

$$
\begin{aligned}
& \text { asugasdiR[.]lai[..]:aih[..]so[.(.)]a[..]i[.] } \operatorname{loruma[..]ib[.]~(Krause)~} \\
& \text { asugasdiz[.]l } \square \text { ại } \square[.] \text { ạ:aihẹkso[..(7)..] orum[...]ib[.] (Knirk) }
\end{aligned}
$$

Both Krause and Knirk have taken the Myklebostad text to start with a non-syntactic statement featuring the name of a man, AnsugastiR, and the description [h]lai[w] 'grave, burial mound', followed by a second expression that starts with an interpunct and the sequence aih (which is usually taken as a form of the verb *aigan 'own, have, claim'). Marstrander (1929), however, went further still, reading a clitic pronoun -ek after aih (as is supported by Knirk's reading) and an early form of ON sómi 'honour, dignity' immediately after the cliticised verb (cf. Nielsen 1969; 1984:10). Most texts 
of this memorialising type feature the name of a man inflected in the genitive except when a verb is employed (e.g. Bø stone's hnabudas hlaiwa 'HnabudaR's grave'; see Krause and Jankuhn 1966, no. 78), but that is clearly not the case at Myklebostad where a verb which alliterates with the opening name appears. Rather than accept that the Myklebostad text begins with a non-syntactic (or elliptical) sequence followed by a verb in sentence-initial position, then, it seems much more plausible to accept that [h]lai[w] a represents the object of the (typically legalistic) verb aih 'I have, I claim', with $A(n)$ sugastiR representing the alliterating onomastic subject. Indeed Marstrander's pronominally cliticised aih-ek suggests that the following parsing should be applied to what remains of the Myklebostad legend:

$\begin{array}{ll}\text { A(n)sugastiR [h]lai[w]a: aih-ek } & \text { 'I, Ansugastiz, claim the mound } \\ \text { sōman bi w]or }{ }^{u} \text { ma[la]ib[a]. } & \text { for compensation by snake- } \\ \text { inheritance.' } & \end{array}$

Clearly the syntax AnsugastiR [h]lai[w] a aih-ek is (still) unexpected, though: other texts of the first-person early runic type would lead us to expect a word order *ek Ansugastir aih hlaiwa (or perhaps even a topicalised *Ansugastir aih-eka hlaiwa ${ }^{8}$ ). Yet the SOV syntax represented in this reading is mirrored in the opening line of the Tune memorial as well as sundry other early runic finds - only the position of the pronominal clitic is unexpected. Whether sō[man] might refer to honour (as in Old Norse) or an extended meaning 'honour-price, wergild, compensation' is rather less clear, though - indeed the whole inscription is so difficult to make out, any interpretation of it must remain quite tentative. Yet if the interpretation of [w]or ${ }^{u}$ ma[la]ib[a] as a kenning (rather than a second anthroponym) is to be accepted (and cf. the apparent rhyme of [h]lai[w]a and -[la]ib[a] which may explain the apparent anastrophe of [h]lai[w]a : aih-ek) the mention of 'snake-inheritance' (i.e. gold) would seem to be most keeping with the payment of an honour price, much as Marstrander's expansion sō[man] also presumes. Above all, though, and much like many other older runic texts, the Myklebostad memorial shows clear signs of stylisation, its syntactic, phonological and semantic manneredness all pointing to a type of poetic composition, albeit one that is not entirely expected from a later Icelandic perspective.

A further (and presumably slightly earlier) example of an alliterating older runic inscription that makes reference to a legal concept was first published in 1993. A clear reference to an aipa- or 'oath' (cf. ON eið 'id.') appears on a late Roman Iron Age find from Nydam, Jutland, which has been dated to the first half of the fourth century. This time the rune-inscribed item represents a sacrifice cast into a cultic lake or bog, and one of the key terms from the text (presumably the verb) is barely legible today. Nonetheless as Herschend $(2001,369)$ has noted, the alliteration that seems to be attested given the reading of Stoklund (1993, 259-61 and 269-70) suggests metrical composition - indeed that of the rare cross-linking ( $a b: a b)$ type declared by Schulte $(2009,17)$ to be a sure sign of "high metrical form":

WagagastiR
alu : wīhju SīkijaR : AipalātaR

${ }^{8}$ Cf. Eythórsson (1995, 184-87; 1996, 132; 2001, 29; 2011, 32-33). 
'(I,) WagagastiR, consecrate alu, (the) wetlander, (the) oath-mannered.'

If taken in what seems to be the most obvious way, the Nydam axe-haft inscription looks to feature a trinomen (WagagastiR Sïkijar AipalātaR) with the second two elements (an ablative and a cognomen or functional title) right dislocated in much the same manner as occurs with a cognomen on the Zealand II (Køge) bracteate. At Zealand the dislocation of the cognomen seems to have been motivated by the alliteration of the idionym Hari(j)ūha with the naming verb haite $\bar{e}^{9}$ - and a similar form of deliberate syntactic distortion motivated by euphony seems to be witnessed at Nydam. Indeed the alliteration suggests chiastic stylisation, with the trinomen straddling (and hence privileging) the dedicatory verb phrase alu wìhju, the verb appearing unexpectedly (as at Tune and Myklebostad) in verb-late position (cf. Watkins 1995, 40-41, 128-29 and 132 on straddling). Grønvik (2000) suggests that Stoklund's reading wịhgu (for expected wīhju) is wrong, however, isolating aih 'owns' (rather than wīh) in the second line (working from a photo), a verb otherwise represented in early runic epigraphy only in the orthographically even more difficult Myklebostad find. But as at Myklebostad, the verb usually alliterates with the subject in stylised early runic texts (cf. Tune W̌̈̌war ... wor ${ }^{a} h t \bar{o}$, dohtriR dālidun, Myklebostad A(n)sugastiR ... aih-ek, Nydam WagagastiR ... wīhju). Only Grønvik's comparison of -lätaR to Old Norse -látr '-mannered, -ful' (where Stoklund had read a morphologically unparalleled nomen agentis '-sayer') seems to represent an obvious improvement on Stoklund's original interpretation, his further suggestion that a better comparison would be with ON lata 'late' (i.e. in the sense 'unwilling') being undermined by the high frequency of constructions in -látr (vis-à-vis -latr) attested later in Norse.

Yet what was meant by AipalātaR? Given the obviously cultic environment, WagagastiR's role could have been as one who was 'mannered' to keep (or uphold) religious vows, much as is suggested by the stereotypical Roman dedicatory formula votum solvit libens merito, 'in fulfilment of a vow, willingly, deservedly' (Keppie 1991, 23): i.e. WagagastiR may have uttered a vow and was fulfilling it by (physically and orthographically) offering the Nydam axe (and, presumably, associated war booty) to the Old Germanic gods. That is, after all, what is usually assumed for the Danish bog finds - that they represent sacrifices of military spoils to the pagan gods of war (Ilkjær and Lønstrup 1982; Lund Hansen 2007). But it is less than clear that a legal oath would have been considered all that different than a religious vow in early runic times. Indeed as Egils saga (56) recounts, Norse assemblies were sometimes bounded by vébönd 'holy ropes', much as if a connection between sacred and juridical spaces was common in Old Germanic tradition (Brink 2004). That might presumably also be the reason why the Icelandic goðar seem to have taken on both legal and political functions (cf. Gothic gudja, early runic gudija 'priest'). Presumably it was goðar who acted as the principal advocates at the Scandinavian ping, the Northern equivalent of the continental mallus (Barnwell 2004). The weaving of arguments by such men could also have been interpreted allusively as akin to the performance of

\footnotetext{
${ }^{9}$ Krause and Jankuhn (1966, no. 127) and cf. Mees (2007, 214-15; 2008, 88-89), Sonderegger (1998, $31)$.
} 
poetry. Indeed a Hibernian perspective on Old Norse legal practice suggests that speeches made by figures like goðar may have even constituted alliterative prose, if not outright poetry (Stacey 2007).

It may be that the Nydam text is better seen in terms of a different (i.e. religious) genre, one featuring what Watkins $(1970=1994,456-72)$, following the semantic distinctions of Alvíssmál, calls the marked "language of the gods" as opposed to the unmarked "language of men", the Tune and Myklebostad memorials principally in light of (only) the other early runic monumental funerary finds. Nonetheless there appears to be good evidence which links legal expressions with linguistic stylisation in early runic tradition - and inscriptions like the Tune, Myklebostad and Nydam finds might well have been thought of as *mapla-/mahla-rūnozz in their time. Indeed there is similarly good evidence that comparable language was still being used in medieval tradition recounted in literary sources. Alliterating expressions are widely used in the lawsuits of Njáls saga 141-44 (e.g. lysi ek heyranda hljóði at Lögbergi, 'I give notice in the hearing of all at the Law Rock'), for example, and Mörðr Gígja who was 'so skilful a lawyer that no judgment was held to be valid unless he had taken part in it' (svá mikill lögmaðr, at engir póttu lögligir dómar domðir, nema hann vari við) is particularly associated with such expressions. Similarly stylised language also appears in eulogies in Old Icelandic prose, a connection between eloquence and praise comparable to Aristotle's (De Rhet. III.18) recommendation that quantitative rhythm was allowable in paeans - and a similar eulogistic use of alliteration might explain the appearance of alliteration in some of the younger runic memorials which do not obviously represent poetry (Lönnroth 1965, 1976, 84-85 and 118-20; Naumann 2010, 145-46). In fact a comparable allowance in early Nordic tradition might explain the alliteration common in the early runic self-predicative or ek texts which seem to represent a sort of stylised prose (Mees 2008, 91-92; Naumann 2010, 147-48). But so prevalent as lawsuits are in Njáls saga, the language used seems to modern interpreters mostly to be restrictive and technical rather than elevated and poetic. Instead of being used for literary effect, the legal language of Njáls saga appears fusty and tedious today - an imposition on, rather than an addition to the narrative (Allen 1971, 173; Lönnroth 1976, 248). Njáls saga seems obsessively focused on procedure and correctness, on legal loopholes, summonses and the swearing of oaths, rather than the use of rhetoric comparable to málrúnar.

\section{A performative account}

The common appearance of roscada or rhetorics in Old Irish legal texts, however, suggests a performative aspect to early Hibernian legal practice that is reminiscent of the málrúnar of Sigrdrifumál. Under Stacey's (2007) interpretation, when the Irish filid argued cases in court they did so using an archaising, mannered form of language comparable to poetic prose (cf. Corthals 1996). And despite the way it appears in Njáls saga, the presence of elevated language in Old Norse law codes might be explained in a similar manner: the alliterative pairs of Scandinavian experience represent expressions that could have been used performatively at cases argued at a ping. Rather than a mnemonic feature, the stylisation of both early Irish and Norse legal language could represent deliberate linguistic elevation for rhetorical purposes.

Yet Stacey's work is fundamentally based on anthropological notions of performance (e.g. Baumann 1977), not sociological or stylistic analysis. Universalist 
anthropologisation of this type can often represent a blunt and clumsy project which passes too readily over specific matters of language, genre and social complexity. And as Schulte (2008) has recently argued, oral-performative theory has sometimes been applied similarly in Old Norse studies without due consideration being given to received cultures of tradition and memory (see McGlynn 2010 for a recent example). The sociological notion of a traditional society (i.e. one where tradition is valued as the main model for social action) also seems absent from much recent theoretical work in the Germanic literary area - it is as if poets of centuries past lived in a farflung (post-)colonial present, rather than in their own particular European historicities, societies and culture. Njáls saga 141 recounts that 'there was much talk at the Law Rock about how well and authoritatively [Mörðr] had spoken' (at Lögbergi var gerr mikill rómr at pví, at honum maeltist vel ok skörulega), the expression maeltist vel ok skörulega being suggestive of the Eddic málrúnar. Yet Mörðr's speech that precedes this comment is full of legal formulas, much as if he were acting as some sort of legal rhetorician or skald. Mörðr's performance is quite unlike that usually assumed for Eddic poets, however - it seems traditional and memorised rather than poetically "generated" in a regular oral-formulaic manner (cf. Mellor 2008). Nonetheless a performative approach to Old Norse legal language which accepts the centrality of tradition may still explain the linguistic stylisation of early Germanic legal experience in a more sophisticated and nuanced way than it has often been in the past.

After all, the notion that the mannered language typical of Old Scandinavian law codes must be accounted as either due to memorisation or oral performance (Brink 2005, 74-77) seems to represent a false dilemma from a sociolinguistic perspective. Modern legal language often remains highly mannered without any conscious need for lawyers to create formulations which need to be remembered or performed. Rather, the reason why American lawyers will still use an expression such as rest, residue and remainder when writing wills is simply because of tradition - it is what lawyers have always done; it seems correct, true and important to them; it provides the wills with gravitas. The use of such language is traditional and conservative: in part it represents a fear that if things are not done as they always have been then a mistake will be made and unexpected consequences may arise (Tiersma 2000). What mnemonic or performative value such expressions may have today is so trivial as to be functionally (and hence analytically) irrelevant. A similar respect for following legal rhetorical conventions (even to the point of travesty) seems abundantly clear in Njáls saga.

The question of how a text or manner of discourse functions is different than an explanation of why it first arose. If a tradition of using alliterative language (as in Old Irish) had arisen in early Nordic legal practice, then its continuance should scarcely be surprising if it had come to be associated with cultivated eloquence. Yet if it was traditional to use elevated language when arguing court cases, when making legal judgements, even when codifying laws, then the primary reason for continuing to use such language may simply have been that it had come to be associated primarily with correctness. Indeed if using certain types of elevated language was considered concomitant with correct legal argument because traditional uses of well-framed words were highly valued, then we should expect to see similar stylisation appear in legal codes. The Old Scandinavian law codes were clearly a leading instrument for establishing social control, the elevated language (or málrúnar) they contain presumably an indication of a linguistic structuration (in the sense of Giddens 1984) 
that came to emphasise correctness through understood reference to prior (correct) performance by men like WagagastiR in the deeper North Germanic past.

\section{References}

Allen 1971: Richard F. Allen, Fire and Iron: Critical Approaches to Njáls Saga, Pittsburgh.

Altmann 1981: Hans Altmann, Formen der "Herausstellung” im Deutschen: Rechtsversetzung, Linksversetzung, Freies Thema und verwandte Konstruktionen (Linguistische Arbeiten; 106), Tübingen.

Antonsen 2002: Elmer H. Antonsen, Runes and Germanic Linguistics (Trends in linguistics: Studies and monographs; 140), Berlin.

Barnwell 2004: Paul Barnwell, "The Early Frankish Mallus: Its Nature, Participants and Practices", in: Assembly Places and Practices in Medieval Europe, eds. Aliki Pantos \& Sarah Semple, Dublin.

Bauer 2010: Alessia Bauer, "Die späten Runica Manuscripta aus Island. Was versteht man unter málrúnir?", in: Futhark 1: 197-224.

Baumann 1977: Richard Baumann, Verbal Art as Performance, Prospect Heights, Ill.

Brink 1996: Stefan Brink, "Forsaringen - Nordens äldsta lagbud", in: Beretning fra femtende tvarfaglige vikingesymposium, eds. Else Roesdahl \& Preben Meulengracht Sørensen, Højbjerg.

- 2004: Stefan Brink, "Legal Assembly Sites in Early Scandinavia", in: Assembly Places and Practices in Medieval Europe, eds Aliki Pantos \& Sarah Semple, Dublin.

- 2005: Stefan Brink, "Verba Volant, Scripta Manent? Aspects of Early Scandinavian Oral Society", in: Literacy in Medieval and Early Modern Scandinavian Culture (Viking collection; 16), ed. Pernille Hermann, Odense.

- 2008: Stefan Brink, "Law and Society: Polities and Legal Customs in Viking Scandinavia", in: The Viking World, eds. Stefan Brink \& Neil Price, London.

Carey 1994: John Carey, "An Edition of the Pseudo-historical Prologue to the Senchas Már", in: Ériu 45: 1-32.

CIH = Corpus iuris hibernici, ad fidem manuscriptorum, ed. Daniel A. Binchy, 6 vols., Dublin, 1978.

Corthals 1996: Johan Corthals, "Early Irish Retoirics and their Late Antique Background", in: Cambrian Medieval Celtic Studies 31: 17-36.

Dilcher 1961: Gerhard Dilcher, Paarformeln in der Rechtssprache des frühen Mittelalters, Darmstadt.

Dishington 2009: James Dishington, "Early Runic witadahalaiban (Tune Stone): Legal Phrase, Not Epithet”, in: Historische Sprachforschung 122: 284-293.

Ehrhardt 1977: Harald Ehrhardt, Der Stabreim in altnordischen Rechtstexten (Skandinavische Arbeiten; 2), Heidelberg.

Eythórsson 1995: Thórhallur Eythórsson, "Verbal Syntax in the Early Germanic Languages", Dissertation, Cornell University.

- 1996: Thórhallur Eythórsson, "Functional Categories, Cliticization and Word Order in the Early Germanic Languages", in: Studies in Comparative Germanic Syntax, Volume II (Studies in Natural Language and Linguistic Theory; 38), eds. Höskuldur Thráinsson, Samuel D. Epstein \& Steve Peter, Dordrecht. 
- 2001: Thórhallur Eythórsson, "The Syntax of Verbs in Early Runic", Working Papers in Scandinavian Syntax 67: 1-55.

- 2011: Thórhallur Eythórsson, "Variation in the Syntax of the Older Inscriptions", Futhark 2: 27-49.

Fix 1982: Hans Fix, "Poetisches im altisländischen Recht: Zur Zwillingsformel in Grágás und Jónsbók", in: Sprachen und Computer: Festschrift zum 75. Geburtstag von Hans Eggers, 9 Juli 1982 (Sprachwissenschaft, Computerlinguistik; 9), eds. Hans Fix, Anneley Rothkegel \& Erwin Stegentritt, Dudweiler.

Giddens 1984: Anthony Giddens, The Constitution of Society: An Outline of the Theory of Structuration, Cambridge.

Grønvik 1976: Ottar Grønvik, "Runeinnskriften fra Eikeland på Jæren”, in: Norsk tidsskrift for sprogvidenskap 30: 133-190.

- 1981: Ottar Grønvik, Runene på Tunesteinen: Alfabet - språkform - budskap, Oslo.

- 1994: Ottar Grønvik, "Kan de gamle runeinskrifter fortelle oss noe om begravelsesriter og om kontakten med de døde i førkristen tid i Norden?", in: Myte og ritual i det førkristne Norden: Et symposium, ed. Jens Peter Schjøldt, Odense.

- 1998: Ottar Grønvik, "Enda en gang om Tuneinnskriften”, in: Maal og Minne (1998): 35-40.

- 2000: Ottar Grønvik, "Die Runeninschrift eines Axtstieles aus dem Moor von Nydam", in: North-Western European Language Evolution (NOWELE) 36: 93111.

Herschend 2001: Frands Herschend, “'Written on Terrestrial Things' - A Discussion of Some Scandinavian Runic Inscriptions up to the 6th century AD", in: Kontinuität und Brüche in der Religionsgeschichte: Festschrift für Anders Hultgård zu seinem 65. Geburtstag am 23.12.2001 (Ergänzungsbände zum Reallexikon der germanischen Altertumskunde; 31), ed. Michael Stausberg, Berlin.

Ilkjær \& Lønstrup 1982: Jørgen Ilkjær \& Jørn Lønstrup, "Interpretation of the Great Votive Deposits of Iron Age Weapons", in: Journal of Danish Archaeology 1: 95103.

Jacobsen 1935: Lis Jacobsen, Forbandelsesformularer $i$ nordiske runeindskrifter (Kungl. vitterhets historie och antikvitets akademiens handlingar; 39.4), Stockholm.

Källström 2010: Magnus Källström, "Forsaringen tillhör 900-talet", in: Fornvännen 105: 228-232.

Keppie 1991: Lawrence Keppie, Understanding Roman Inscriptions, London.

Knirk 2002: James E. Knirk, "Myklebostad. §2. Runologisches", in: Reallexikon der germanischen Altertumskunde, eds. Heinrich Beck, Dieter Geuenich \& Heiko Steuer, 2nd ed., Berlin, 20: 453-454.

- 2006: James E. Knirk, "Tune (Østfold). B. Runological”, in: Reallexikon der germanischen Altertumskunde, eds. Heinrich Beck, Dieter Geuenich \& Heiko Steuer, 2nd ed., Berlin, 31: 332-335.

Krause 1934: Wolfgang Krause, "Germanisch arja- 'vornehm' auf dem Stein von Tune", in: Forschungen und Fortschritte 10: 217-218.

- 1971: Wolfgang Krause, Die Sprache der urnordischen Runenischriften (Germanische Bibliothek. III. Reihe. Untersuchungen und Einzeldarstellungen), Heidelberg. 
Krause \& Jankuhn 1966: Wolfgang Krause \& Herbert Jankuhn, Die Runeninschriften in älteren Futhark. (Abhandlungen der Akademie der Wissenschaften in Göttingen, Philologisch-Historische Klasse, Dritte Folge, Nr. 66), Göttingen.

Lehmann 1956: Winfred P. Lehman, The Development of Germanic Verse Form, Austin.

Lejeune 1971: Michel Lejeune, Lepontica (Monographies linguistiques; 1), Paris.

Liestøl 1979: Aslak Liestøl, "Runeringen i Forsa. Kva er han, og når vart han smidd?", in: Saga och sed (1979): 12-27.

Lönnroth 1965: Lars Lönnroth, "Det litterära porträttet i latinsk historiografi och isländsk sagaskrivning - en komparativ studie", in: Acta Philologica Scandinavica 27: 68-117.

- 1976. Lars Lönnroth, Njál's Saga: A Critical Introduction, Berkeley.

Lund Hansen 2007: Ulla Lund Hansen, "Barbarians in the North - The Greatest Concentrations of Roman Weaponry in Europe", in: Beyond the Roman Frontier: Roman Influences on the Northern Barbaricum (Analecta Romana Instituti Danici: Supplementum; 39), ed. Thomas Grane, Rome.

MacLeod \& Mees 2006: Mindy MacLeod \& Bernard Mees, Runic Amulets and Magic Objects, Woodbridge.

Markey 1998: Thomas L. Markey, "Studies in Runic Origins 1: Germanic *maplImahl- and Etruscan me日lum", in: American Journal of Germanic Linguistics and Literatures 19: 153-200.

Marold 2001: Edith Marold, "Ljóðaháttr", in: Reallexikon der germanischen Altertumskunde, eds. Heinrich Beck, Dieter Geuenich \& Heiko Steuer, 2nd ed., Berlin, 18: 535-540.

- 2011: Edith Marold, "Vers oder nicht Vers? Zum metrischen Charakter von Runeninschriften im älteren Futhark", in: Futhark 2: 63-102.

Marstrander 1929: Carl J.S. Marstrander, "Myklebostadstenen", in: Norsk tidsskrift for sprogvidenskap 3: 197-217.

- 1930: Carl J.S. Marstrander, “Tunestenen”, in: Norsk tidsskrift for sprogvidenskap 4: 294-358.

McGlynn 2010: Michael P. McGlynn, "Bergpór's Voice: Orality in the Homicide Laws of the Old Icelandic Grágás", in: Amsterdamer Beiträge zur älteren Germanistik 66: 75-102.

Mees 2007: Bernard Mees, "Before Beowulf: On the Proto-history of Old Germanic Verse", in: Journal of the Australian Early Medieval Association 3: 209-223.

- 2008: Bernard Mees, "Style, Manner and Formula in Early Germanic Epigraphy", in: North-Western European Language Evolution (NOWELE) 54/55: 63-98.

Mellor 2008: Scott A. Mellor, Analyzing Ten Poems from The Poetic Edda: Oral Formula and Mythic Patterns, Lewiston.

Meritt 1938: Herbert D. Meritt, The Construction apo koinou in the Germanic Languages (Stanford University Publications, University Series: Language and Literature; vi.2), Stanford.

Moltke 1985: Erik Moltke, Runes and their Origin, Denmark and Elsewhere, trans. Peter G. Foote, Copenhagen.

Naumann 1998: Hans-Peter Naumann, "Runeninschriften als Quelle der Versgeschichte", in: Runeninschriften als Quellen interdisziplinärer Forschung: Abhandlungen des Vierten Internationalen Symposiums über Runen und 
Runeninschriften in Göttingen vom 4.-9. August 1995 (Ergänzungsbände zum Reallexikon der germanischen Altertumskunde; 15), ed. Klaus Düwel, Berlin.

- 2010. Hans-Peter Naumann, "Zum Stabreim in Runeninschriften”, in: Jahrbuch für internationale Germanistik 42: 143-166.

NIaR = Norges Indskrifter med de aldre Runer (Norges Indskrifter indtil Reformationen; I), eds. Sophus Bugge \& Magnus Olsen, 3 vols. Christiania, 18911924.

Nielsen 1969: Niels Åge Nielsen, "Der Runenstein von Myklebostad”, Kopenhagener germanistiche Studien 1: 237-249.

- 1984: Niels Åge Nielsen, Fra Runesprog til Nudansk: Studier og kommenterende tekster, Aarhus.

Norén 2007: Niklas Norén, Apokoinou in Swedish Talk-in-interaction: A Family of Methods for Grammatical Construction and the Resolving of Local Communicative Projects (Linköping Studies in Arts and Science; 405 / Studies in Language and Culture; 11), Linköping.

Ruthstrøm 1990: Bo Ruthstrøm, “Forsa-ristningen - vikingatida vi-rätt?”, in: Arkiv för nordisk filologi 105: 41-56.

Schulte 2008: Michael Schulte, "Literacy in the Looking Glass: Vedic and Skaldic Verse and the Two Modes of Oral Transmission", in: Scripta Islandica 59: 181199.

- 2009: Michael Schulte, "Early Runic 'Metrical' Inscriptions - How Metrical are They?", in: Versatility in Versification: Multidisciplinary approaches to metrics (Berkeley Insights in Linguistics and Semiotics; 74), eds. Tonya Kim Dewey \& Frog, New York.

- 2010: Michael Schulte, "Runes and Metrics: On the Metricity of the Older Runic Inscriptions", in: Maal og Minne (2010): 45-67.

- 2011: Michael Schulte, "Early Scandinavian Legal Texts. Evidence for Pre-literary Metrical Composition?", in: North-Western European Language Evolution (NOWELE) 62/63: 1-30.

Sonderegger 1998: Stefan Sonderegger, "Dichterische Wortstellungstypen in Altgermanischen und ihr Nachleben in älteren Deutsch", in: Historische germanische und deutsche Syntax: Akten des internationalen Symposiums anlässlich des 100. Geburtstages von Ingerid Dal, Oslo, 27.9.-1.10. 1995 (Osloer Beiträge zur Germanistik; 21), ed. John Ole Askedal, Frankfurt a.M.

Spurkland 2005: Terje Spurkland, Norwegian Runes and Runic Inscriptions, trans. Betsy van der Hoek, Woodbridge.

Stacey 2007: Robin Chapman Stacey, Dark Speech: Law and Performance in Early Ireland, Philadelphia.

Stoklund 1993: Marie Stoklund, "Runer 1993", in: Arkaoologiske udgravninger $i$ Danmark (1993): 259-274.

Tiersma 2000: Peter M. Tiersma, Legal Language, Chicago.

Vendell 1897: Herman Vendell, Bidrag till kännedomen om alliterationer och rim $i$ Skandinaviskt lagspråk, Helsingfors.

Watkins 1970: Calvert Watkins, "Language of Gods and Language of Men: Remarks on Some Indo-European Metalinguistic Traditions", in: Myth and Law among the Indo-Europeans: Studies in Indo-European Comparative Mythology, ed. Jaan Puhvel, Berkeley. 
- 1994: Calvert Watkins, Selected Writings (Innsbrucker Beiträge zur Sprachwissenschaft; 80), ed. Lisi Oliver, 2 vols., Innsbruck.

- 1995: Calvert Watkins, How to Kill a Dragon: Aspects of Indo-European Poetics, New York.

West 2007: Martin L. West, Indo-European Poetry and Myth, Oxford. 